論文

$$
\begin{gathered}
\text { カルシウムイオン濃度が異なる水中に保存した岩石での鉱物析出 } \\
\text { 奈良 禎太* 桑谷 隆太 } \\
\text { ** 河野 勝宣 }{ }^{* * *} \text { 佐藤 稔紀**** 柏谷 公希***** }
\end{gathered}
$$

\title{
Precipitation of Minerals on Rock Kept in Water with Different Calcium Ion Concentrations
}

by

Yoshitaka NARA*, Ryuta Kunatani**, Masanori Kohno***, Toshinori SATO $* * * *$ and Koki KaShIWAYA*****

Information of confining ability of rock is important for the geological disposal of radioactive wastes. To maintain or improve the confining ability of rocks, it is important to seal pores and cracks. Usually, pores and cracks in rock are sealed over geological time scales. If sealing of pores and cracks in rock can be accelerated and completed by precipitation of minerals, the method would be effective for use during radioactive waste disposal. In this study, we investigated the precipitation of minerals onto the rock surface, to consider whether sealing of pores and cracks in rock can be accelerated. As rock samples, we used Berea sandstone and Toki granite in this study. It was shown that precipitation occurred clearly on the surface of rock specimens kept in calcium hydroxide solution for 1 month if the concentration was high. Specifically, if the concentration of calcium hydroxide solution was higher than $589 \mathrm{mg} / \mathrm{l}$, the precipitation occurred obviously. After keeping rock specimens in calcium hydroxide solution, the weight of the rock samples increased and the concentration of calcium ion decreased by the precipitation. It is considered that the calcium ion in water was used for the precipitation on rock surfaces. Since the precipitation has been recognized for rock specimens, it is concluded that the sealing of pores and cracks in rocks by the mineral precipitation is possible.

\section{Key words:}

Precipitation, Granite, Sandstone, Calcium, Scanning electron microscope

\section{1 緒言}

放射性廃棄物地層処分を考える上では，岩盤が高い遮 へい性能を有することが望ましい. 岩盤に存在するき裂 を進展および連結させず，さらに閉塞させることができ れば，岩盤の遮へい性能の保持が期待できる，ゆえに， き裂の閉塞を考えることは，放射性廃棄物地層処分を考 える上で有意義である.

Sano et al. ${ }^{1)}$ ， Nara et al. ${ }^{2) ， W a n g ~ e t ~ a l . ~}{ }^{3)}$ 等の研究では，圧 力がかかる環境下において，岩石内のき裂が閉塞するこ とが示されている. Ishibashi et al. ${ }^{4}$ は，地下水中に含まれ る粘土鉱物が沈殿することにより岩盤内のき裂が閉塞 することを報告している. 地下岩盤を長期的に利用する 場合には，力学的作用だけではなく化学的作用が岩盤の 性質に影響を及ぼす可能性がある，例えば，水中環境下 では, 圧力下で鉱物が溶解した後に沈殿が起こり, 空隙 が閉塞するという, 力学と化学の相互作用による欠陥の 閉塞現象が報告されている5),6).

一方で，化学作用のみによる岩石内のき裂閉塞（き裂 修復）は十分に調べられていない。化学作用のみでのき
裂閉塞は, セメント系材料で認められているように, 鉱 物の析出により生じることが考えられる 7) 99. 放射性廃 棄物処分施設を建設する場合, 大量のセメント系材料が 使用されると考えられる。 そのため, 周辺の地下水の力 ルシウムイオン濃度は高くなると予想され，カルシウム 化合物が岩石表面に析出することによってき裂の閉塞 が生じる可能性が考えられる. しかし, 水中における岩 石表面への鉱物析出挙動は十分に調べられていない. そこで本研究では，カルシウム分を含む水中環境に 1 ケ月岩石を保存することによって, 岩石表面に鉱物が析 出するかどうかを調べることとした．特に，カルシウム イオン濃度の異なる環境下に岩石を保存した場合, 岩石 表面への鉱物析出がどのように異なるかについて調べ， 岩石表面での鉱物析出が生じるカルシウムイオン濃度 がどの程度であるかを調べることとした。

\section{2 岩 石 試 料}

本研究では，土岐花崗岩とベレア砂岩を試料として用 いた。土岐花崗岩試料は，瑞浪市の日本原子力研究開発

$\dagger$ 原稿受理 平成29年8月9日 Received Aug. 9, 2017 C2018 The Society of Materials Science, Japan

* 正会員 京都大学 大学院工学研究科 $=615-8540$ 京都市西京区京都大学桂 Graduate School of Engineering, Kyoto University, Nishikyo-ku, Kyoto 615-8540

** 鳥取大学 工学部 土木工学科 $\bar{T} 680-8552$ 鳥取市湖山町南4-101 Faculty of Engineering, Tottori University, Koyama-cho Minami, Tottori 680-8552

**** 鳥取大学 大学院工学研究科 $=680-8552$ 鳥取市湖山町南4-101 Graduate School of Engineering, Tottori University, Koyama-cho Minami, Tottori 680-8552

****正 会 員 日本原子力研究開発機構 幌延深地層研究センター $\overline{0} 098-3224$ 北海道天塩郡幌延町字北進432番地2 Horonobe Underground Res. Center, Japan Atomic Energy Agency (JAEA), Teshio-gun, Hokkaido 098-3224

******京都大学 大学院工学研究科 $\overline{7} 615-8540$ 京都市西京区京都大学桂

Graduate School of Engineering, Kyoto University, Nishikyo-ku, Kyoto 615-8540 
機構の地下研究施設より得られた, 中粒〜粗粒の黒雲母 花崗岩であり，空隙率は $0.78 \%$ である. Fig. 1 に，インタ クトな土岐花崗岩の走査型電子顕微鏡画像を示す. ベレ ア砂岩は，アメリカ合衆国才八イオ州産の砂岩であり， 平均粒径は $0.1 \mathrm{~mm}$ 程度の均質な砂岩で，空隙率は $20.4 \%$ である、X 線回折分析より, ベレア砂岩の主要な造岩鉱 物は石英であり，その他は微少な量の斜長石やカリ長石 で構成されていることが報告されている ${ }^{10)}$. Fig. 2 に, インタクトなベレア砂岩の走査型電子顕微鏡画像を示 す。本研究では, 直径 $30 \mathrm{~mm}$, 厚さ $20 \mathrm{~mm}$ の円柱試験片 を作成し, 岩石表面での鉱物析出について調べた。

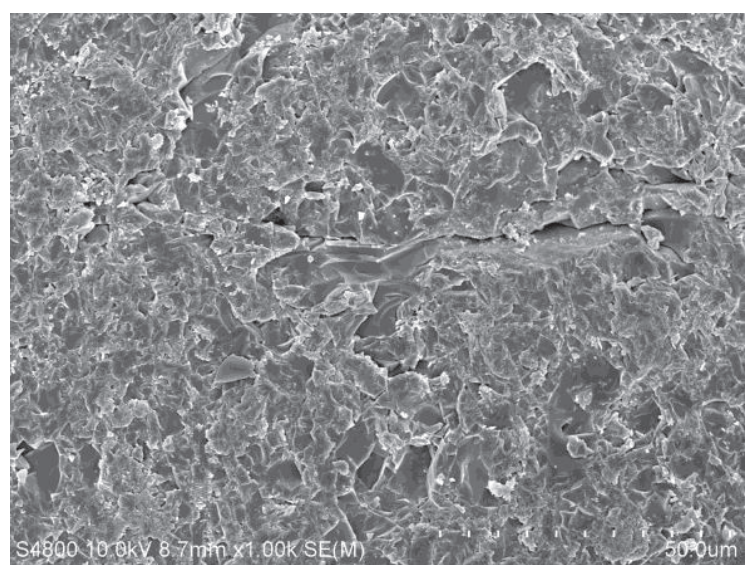

Fig. 1 Scanning electron photomicrograph of intact Toki granite. The height and width of this image is $0.096 \mathrm{~mm}$ and $0.128 \mathrm{~mm}$, respectively.

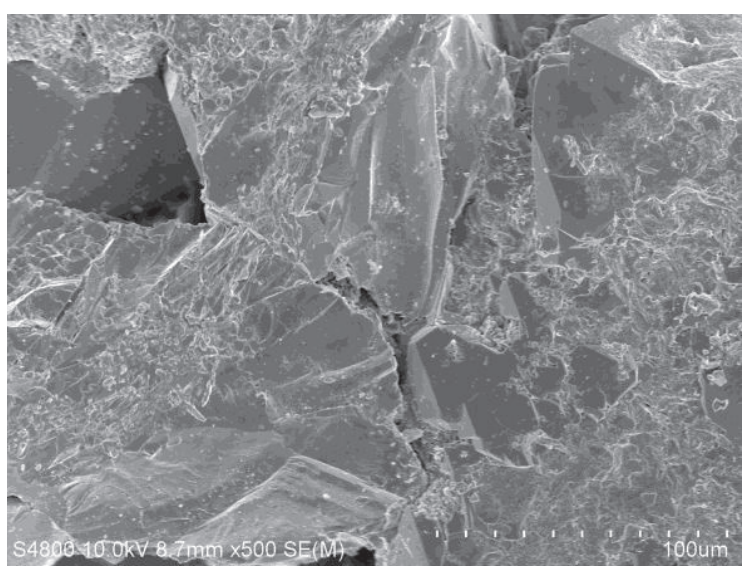

Fig. 2 Scanning electron photomicrograph of intact Berea sandstone. The height and width of this image is $0.192 \mathrm{~mm}$ and $0.256 \mathrm{~mm}$, respectively.

\section{3 試 験 方 法}

ボーリングマシン, カッター, 平面研削盤等を用いて 円柱試験片を作成した後， 2 週間自然乾燥させ， $80^{\circ} \mathrm{C}$ に 設定したオーブンで 24 時間強制乾燥させる。この際, 急激な温度変化を避けるため, 1 分につき $1{ }^{\circ} \mathrm{Cずつオー}$ ブン内の温度を変化させて, 岩石試験片を乾燥させた。 続いて, 電子天科 (分解能 $0.0001 \mathrm{~g}$ ) を用いて岩石試験片 の重量を測定した。 その後, 岩石試験片をプラスチック 容器（容量 $400 \mathrm{ml}$, 重量 $21.70 \mathrm{~g}$ ) 内に水酸化カルシウム
水溶液 $300 \mathrm{ml}$ と共に保存した。このとき，水酸化カルシ ウム水溶液の濃度を測定した直後に岩石試験片を水中 に保存している。 さらに, 試験片全体が水溶液中に浸さ れるように注意した。また，試験片と水酸化カルシウム 水溶液の入ったプラスチック容器をグローブバッグに 入れ，グローブバッグ内を窒素で充填することにより， 保存容器内の空気が窒素で置換されるようにした。この 際，グローブバッグ内の窒素濃度を窒素濃度計（アズワ ン製 AJX-N2B）で測定したところ，窒素濃度は 94\%であ り，二酸化炭素濃度計（エムケー・サイエンティフィッ ク製 CDHT2000）で測定した内部の二酸化炭素濃度は $25 \mathrm{ppm}$ であった。保存容器およびその中の岩石試料は, 1 ケ月室温 $\left(20^{\circ} \mathrm{C}\right)$ で保管した。その後，岩石試験片を 取り出し, 前述の二酸化炭素濃度下の空気中で自然乾燥 させた後, 分析天科による重量測定と, デジタルカメラ および走査型電子顕微鏡による表面観察を行った.

Iwatsuki et al. ${ }^{111}$ によると，瑞浪市において測定された 地下水中のカルシウムイオン濃度は, 最高で $639 \mathrm{mg} / 1$, 最低で $2.7 \mathrm{mg} / 1$ である。そこで本研究では，この範囲を おおよそ網羅するようなカルシウム濃度となる水酸化 カルシウム水溶液を 6 種用意し，岩石試験片を保存する こととした. Table 1 に, 本研究で用意した水酸化カルシ ウム水溶液の初期濃度（カルシウムイオン濃度）を保存 した岩石試験片ごとにまとめる。カルシウムイオン濃度 は，周辺大気環境下で，堀場製作所製のポータブルイオ ン濃度メーター（D-73）にカルシウムイオン電極（658310C）を接続して測定した.この際, 水中にカルシウムイ オン電極を 20～30 分間程度入れて，イオン濃度メータ 一の数值が安定するのを待つことによってカルシウム イオン濃度を測定した。なお，岩石試料を保存した水酸 化カルシウム水溶液中には, 水酸化カルシウム試薬の粉 末は一切含まれておらず，す心゙ての試薬が水に溶解した 状態となっていた。ゆえに本研究では，グラウトのよう なセメント系材料の充填や, 粘土のような微細粒子の充 填とは異なり, 周辺水中からの物質の析出による変化を 調べている.

Table 1 Calcium ion concentration in calcium hydroxide solution at initial condition.

\begin{tabular}{|c|c|}
\hline Berea sandstone & Toki granite \\
\hline Concentration: $15 \mathrm{mg} / 1$, & Concentration: $10 \mathrm{mg} / 1$ \\
Specimen: BS-10 & Specimen: TG-10 \\
\hline Concentration: $56 \mathrm{mg} / 1$, & Concentration: $52 \mathrm{mg} / 1$ \\
Specimen: BS-50 & Specimen: TG-50 \\
\hline Concentration: $98 \mathrm{mg} / 1$, & Concentration: $94 \mathrm{mg} / 1$ \\
Specimen: BS-100 & Specimen: TG-100 \\
\hline Concentration: $319 \mathrm{mg} / 1$ & Concentration: $278 \mathrm{mg} / 1$ \\
Specimen: BS-300 & Specimen: TG-300 \\
\hline Concentration: $589 \mathrm{mg} / 1$ & Concentration: $589 \mathrm{mg} / 1$ \\
Specimen: BS-600 & Specimen: TG-600 \\
\hline Concentration: $1150 \mathrm{mg} / 1$ & Concentration: $1150 \mathrm{mg} / 1$ \\
Specimen: BS-1200 & Specimen: TG-1200 \\
\hline
\end{tabular}



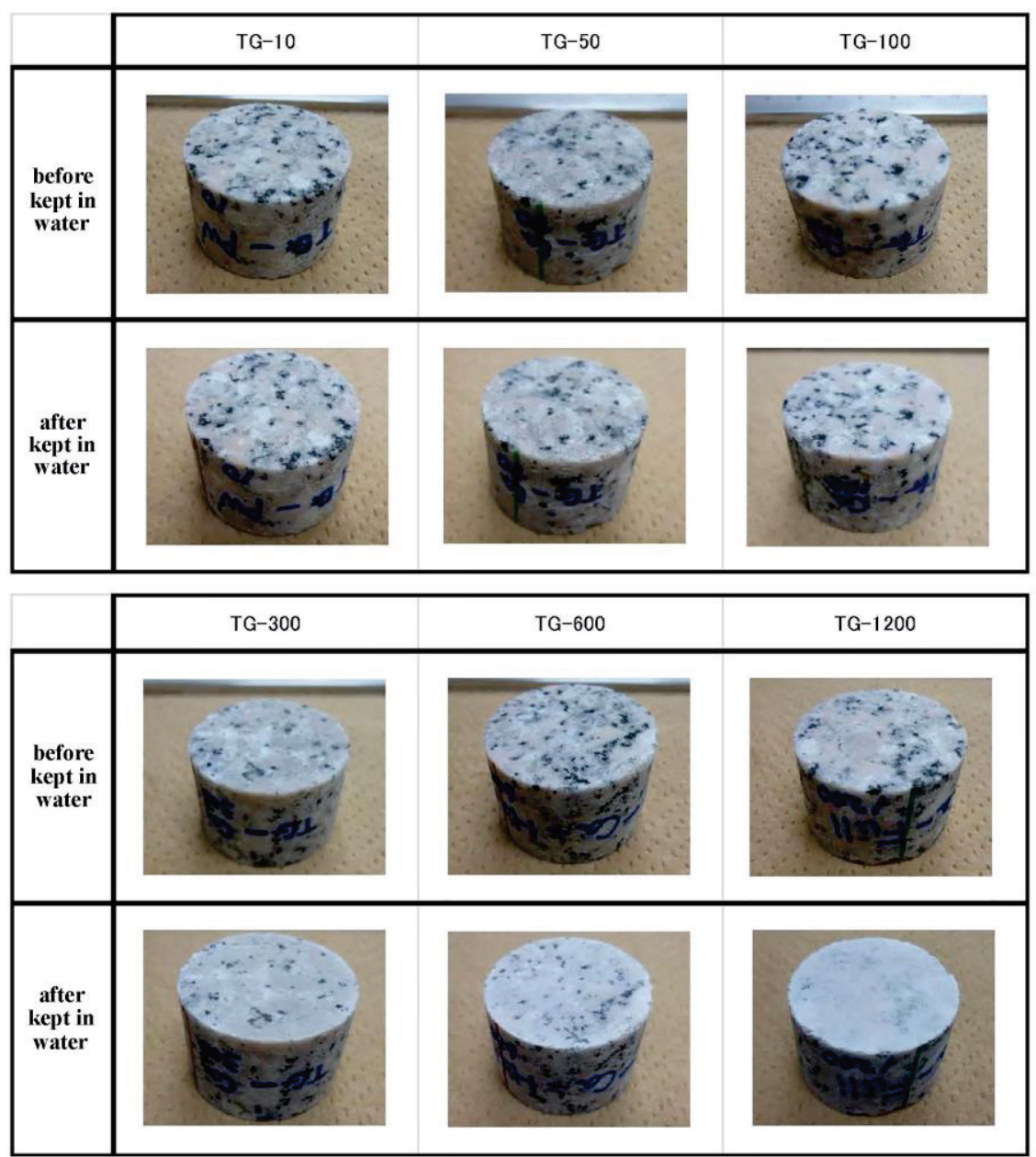

Fig. 3 Photos of Toki granite before and after kept in calcium hydroxide solution for 1 month. The diameter of the rock sample is $3 \mathrm{~mm}$.

\section{4 試 験 結 果}

岩石を 1 ケ月水酸化カルシウム水溶液中に保存した後 に試料表面および保存容器（プラスチック容器）を目視 および重量の変化から調べた結果, 鉱物の析出は岩石表 面および水面のみで生じており, 容器表面では確認され なかった，本研究では，岩石表面で生じた析出物を調查 対象とし, 水面で生じた析出物は調査していない。

Fig. 3 および Fig. 4 に，土岐花崗岩およびベレア砂岩 試験片の水中保存前後での写真をそれぞれ示す。これら より，両方の岩石で，水中のカルシウムイオン濃度が高 い場合に，岩石表面が析出物により白くなっていること が確認できる。特に, 初期カルシウムイオン濃度が $589 \mathrm{mg} / 1$ （約 600mg/l）より高くなると，岩石表面での明 確な析出物の発生が確認できた。

Fig. 5 に, 水中保存前後での試験片の重量変化を示す. なお，重量測定は，「3. 試験方法」で示した二酸化炭素 濃度下の空気中で自然乾燥させた後, $80^{\circ} \mathrm{C} て ゙ 24$ 時間乾 燥させてから行った. Fig. 5 より, 両方の岩石で, 比較 的濃度が高い水酸化カルシウム水溶液中に保存したと きに, 明確な重量増加が確認できた. 特に, カルシウム イオン濃度が高いほど重量増加分が大きくなっている
傾向があることがわかる．また，ベレア砂岩の方が，土 岐花崗岩よりも重量の増加がより大きいことがわかる.

Fig. 6 に, 試験片の保存前後での水中のカルシウムイ オン濃度変化を示す。この図より, 土岐花崗岩とベレア 砂岩両方において, カルシウムイオン濃度の減少が確認 できた。これより，水中のカルシウムイオンが鉱物析出 に用いられたことが示唆される。また，重量変化同様に カルシウムイオン濃度が高いほど減少分が大きくなっ ている傾向があるといえる，なお，本研究では，水中の カルシウムイオン濃度は, 周辺大気環境下で測定してい る.したがって, 試験片保存後に測定されたカルシウム イオン濃度および保存前後での水中のカルシウムイオ ン濃度変化には，大気中に含まれる二酸化炭素と水面付 近のカルシウムイオンが反応して生じる鉱物析出によ るカルシウムイオン減少分も含まれている.

Fig. 7 に土岐花崗岩，Fig. 8 にベレア砂岩の，水酸化力 ルシウム水溶液中に 1 ケ月保存した後の走査型電子顕微 鏡画像を示す。これらの図から，カルシウムイオン濃度 が低い場合（初期濃度 $100 \mathrm{mg} / 1$ 末満）ではほとんど析出 が生じていないものの，濃度が高い場合に試験片表面へ の析出が顕著になることがわかる. 

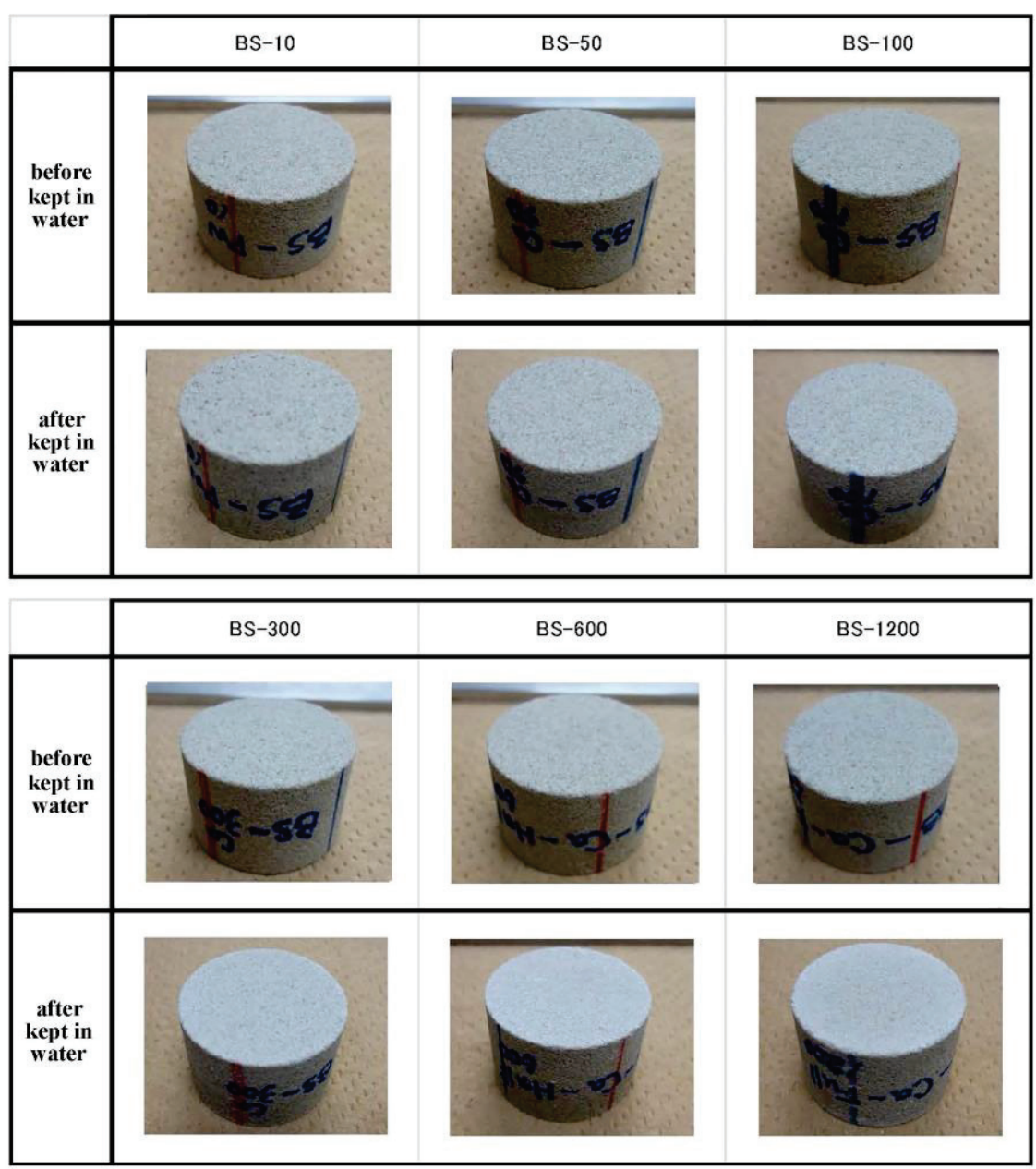

Fig. 4 Photos of Berea sandstone before and after kept in calcium hydroxide solution for 1 month. The diameter of the rock sample is $3 \mathrm{~mm}$.

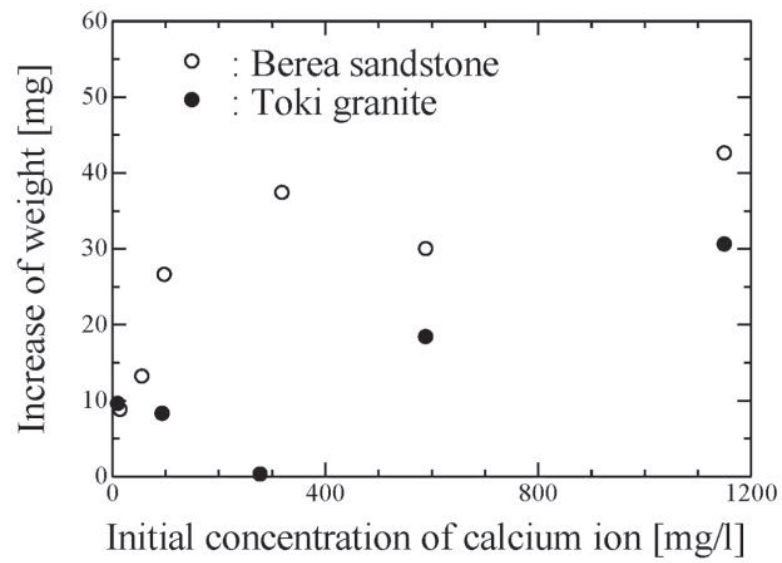

Fig. 5 Increase of weight of rock specimens kept in calcium hydroxide solution for 1 month.

\section{5 考察}

本研究で得られた結果より, カルシウムイオン濃度の高 い水中（水酸化カルシウム水溶液）に保存した場合，鉱 物析出が明確に認められた。土岐花崗岩, ベレア砂岩の 両方において, カルシウムイオン濃度の低い水中では, 岩石供試体の水中保存前後での目視での変化はあまり 見られなかった。一方, カルシウムイオン濃度の高い水 中に保存している試験片ほど表面の析出が増え白くな っていることも示されている，また，重量変化同様に，

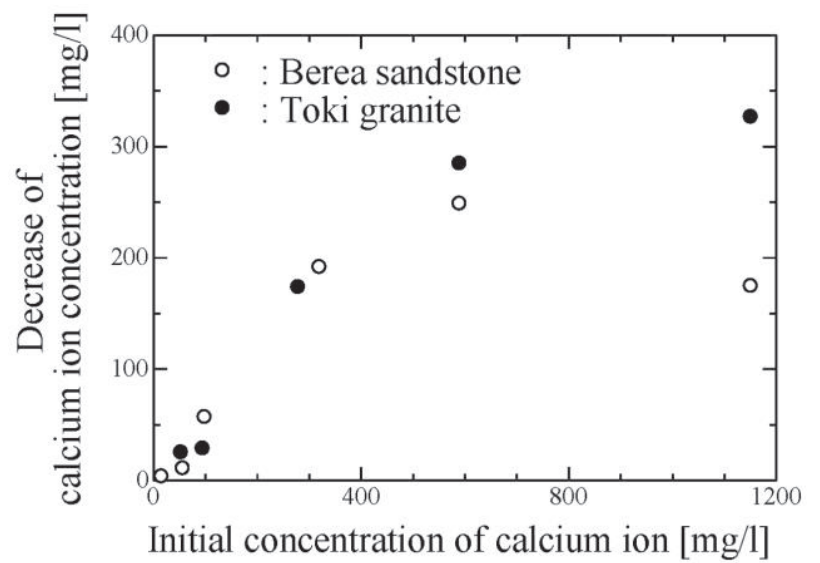

Fig. 6 Decrease of calcium ion concentration in water after keeping rock specimen for 1 month.

初期の濃度が高いほど, 岩石試験片の保存後でカルシウ ムイオン濃度がより多く減少している傾向が認められ ている.このことから，本研究で認められた鉱物析出に は，水中のカルシウムイオンが寄与しているといえる. 本研究では, 水酸化カルシウム水溶液中に岩石を保存 するという条件で鉱物析出を確認したが，過去に行われ た研究では, より多くの電解質が含まれる水中での鉱物 析出が確認されている，例えば Fukuda et al. ${ }^{9}$ は，様々な 電解質を含む人工海水中に高強度高緻密コンクリート 


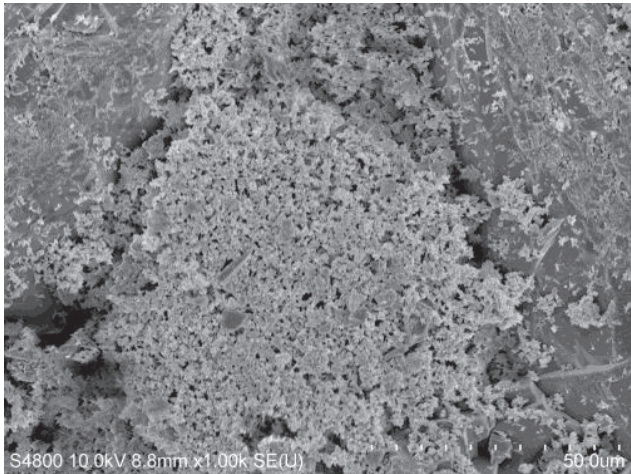

(a)

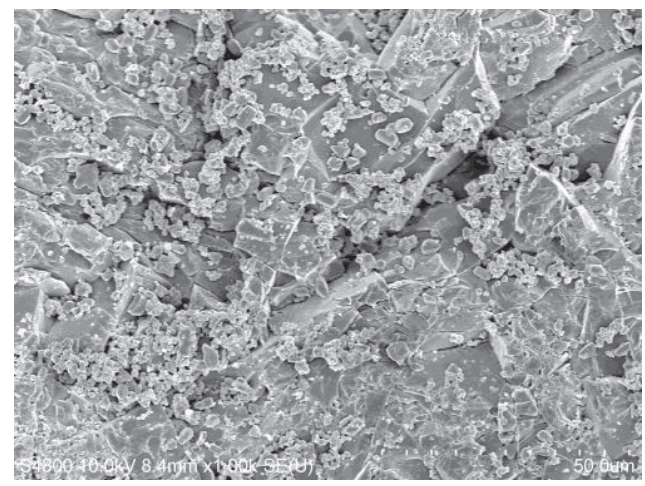

(c)

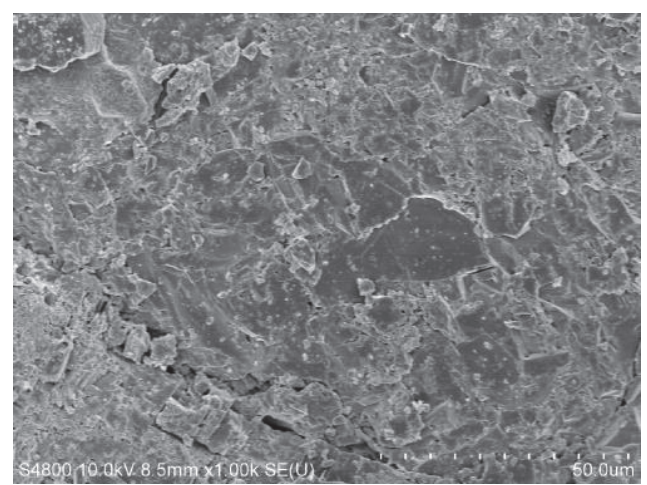

(e)

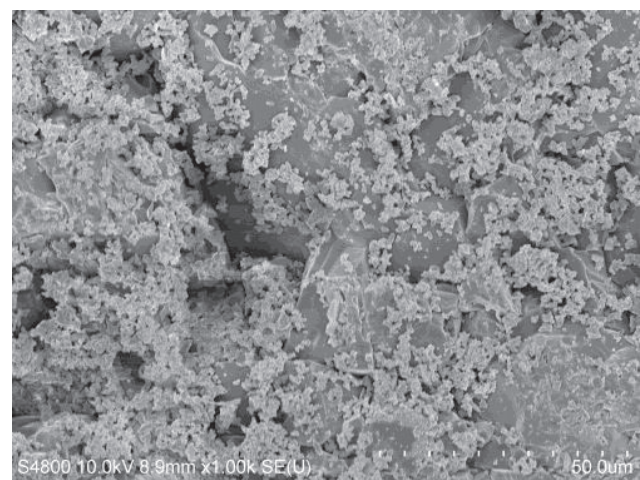

(b)

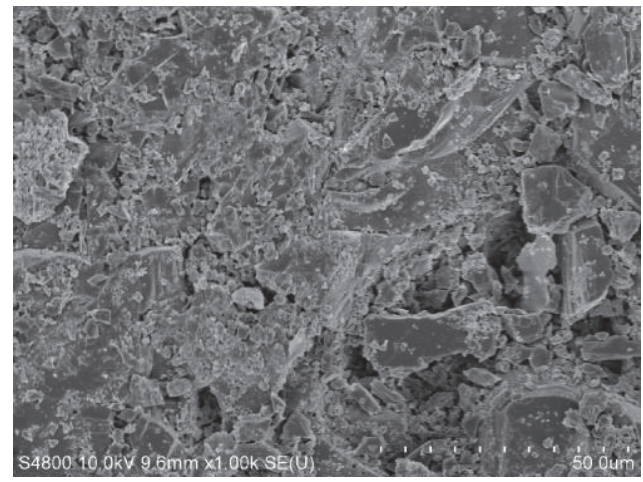

(d)

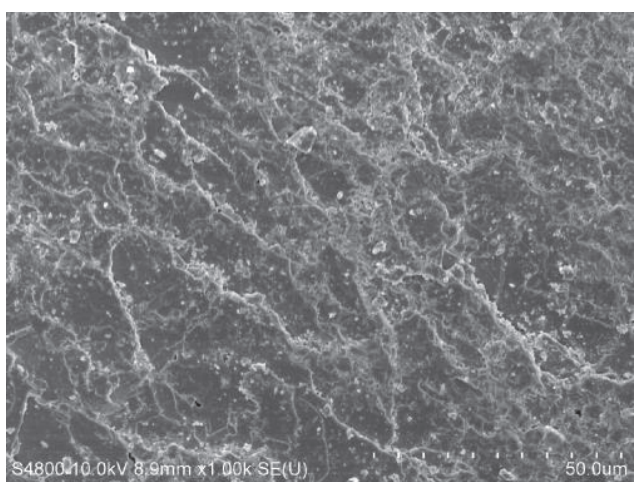

(f)

Fig. 7 Scanning electron photomicrographs of Toki granite after kept in calcium hydroxide solution for 1 month with initial concentration of (a) $1150 \mathrm{mg} / \mathrm{l}$, (b) $589 \mathrm{mg} / \mathrm{l}$, (c) $278 \mathrm{mg} / \mathrm{l}$, (d) $94 \mathrm{mg} / \mathrm{l}$, (e) $52 \mathrm{mg} / \mathrm{l}$, and (f) $10 \mathrm{mg} / \mathrm{l}$. Width and height of the image are $0.096 \mathrm{~mm}$ and $0.128 \mathrm{~mm}$, respectively.

を保存することによって，石英や長石等の鉱物粒子上に 炭酸カルシウム $\left(\mathrm{CaCO}_{3}\right)$ の析出が起こることを確認し ている. また, Fukuda et al. ` $^{9}$ は, $\mathrm{CaCO}_{3}$ は, 水中のカル シウムイオンと炭酸水素イオン $\left(\mathrm{HCO}_{3}{ }^{-}\right)$が反応するこ とによって生じていると報告している. 本研究では水酸 化カルシウム水溶液を用いたことから，析出に寄与寸る 陽イオンは $\mathrm{Ca}^{2+}$ のみと考えられる。また, 大気中の二酸 化炭素の溶解を完全に防ぐことは不可能であることか ら, 炭酸イオンも必然的に水中に含まれる.ゆえに, Fukuda et al.9 によって報告されているように, 本研究で も $\mathrm{CaCO}_{3}$ の析出が岩石試験片表面で起こったと考えら れる.

この考察を検証するため, 同一の試験条件を再現して 岩石試料に析出物を生じさせ, X 線回折分析を行った. 初期 $\mathrm{Ca}^{2+}$ 濃度が高い溶液（589mg/l 以上）に保存した岩
石試料を用いてX 線回折分析を行った結果を Fig. 9 に示 す．この図より，カルシウム化合物としては，カルサイ トのピークのみ検出されていることが示されている. 本 研究で用いたインタクトな土岐花崗岩 12), 13)およびベレ ア砂岩 ${ }^{10)}$, 14)の試料では, 炭酸塩鉱物の含有は認められて いない.ゆえに，上記の推測のとおり， $\mathrm{CaCO}_{3}$ の析出が 岩石試験片表面で起こり, 水酸化カルシウム水溶液中に 含まれていたカルシウムイオンが析出に寄与寸るとい える.

カルシウムイオン濃度が同一条件下での土岐花崗岩 とベレア砂岩の重量変化を比較すると, すべての場合に おいて, ベレア砂岩の方がより大きく重量が増加してい ることがわかる。これは, ベレア砂岩の間隙率が土岐花 崗岩よりも大きく, その分だけ表面積が大きくなってい るためと考えられる. Nakao et al. $\left.{ }^{15}\right)$ は, 複数種の岩石を 


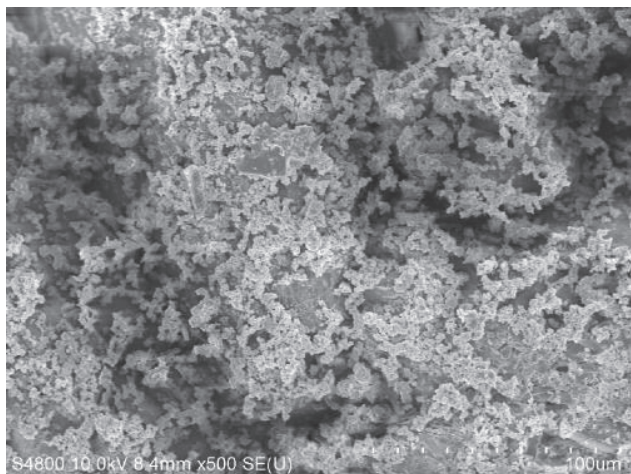

(a)

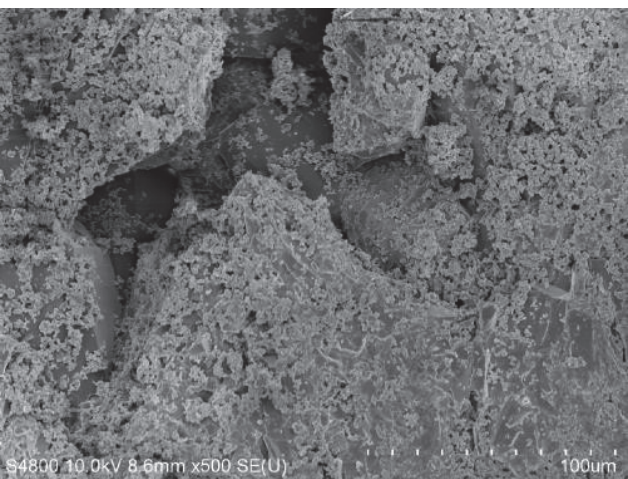

(c)

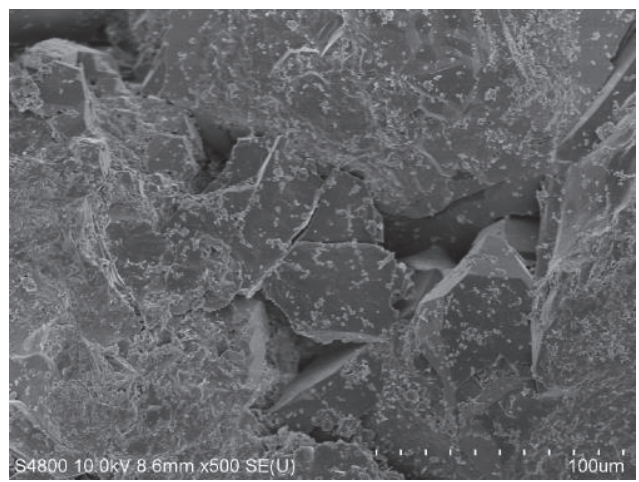

(e)

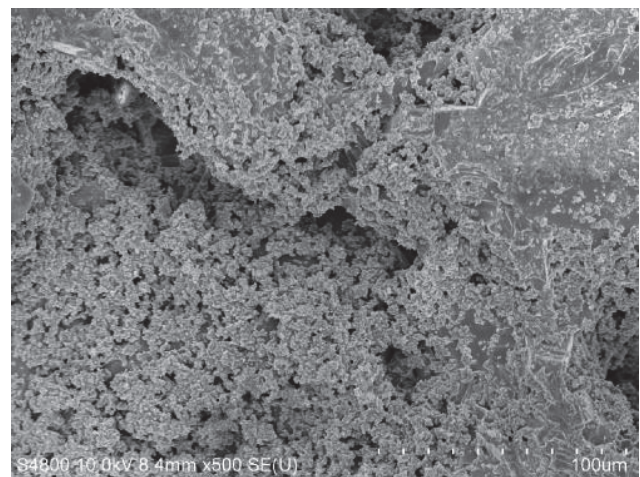

(b)

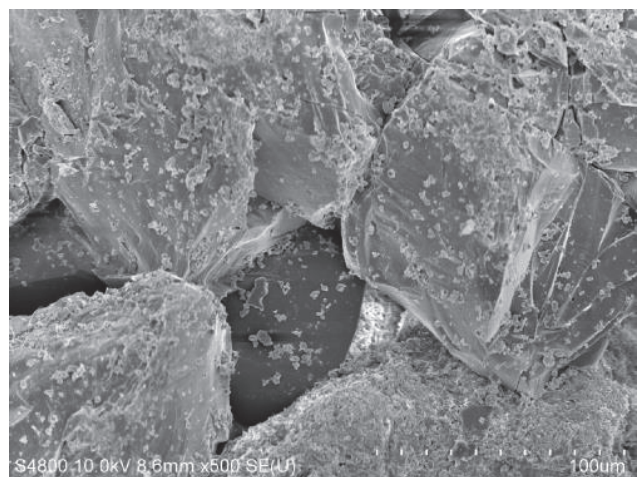

(d)

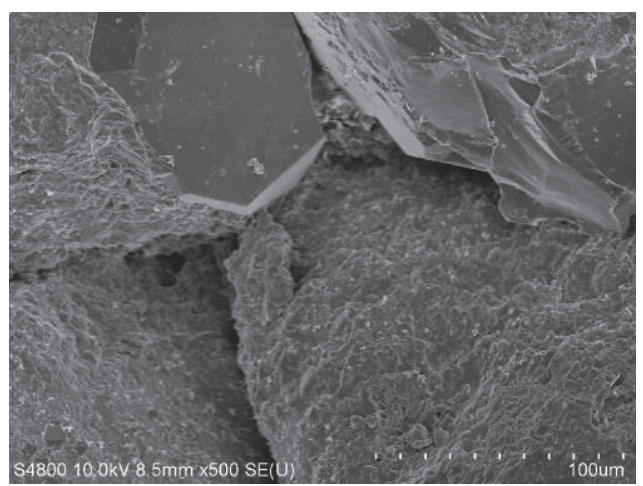

(f)

Fig. 8 Scanning electron photomicrographs of Berea sandstone after kept in calcium hydroxide solution for 1 month with initial concentration of (a) $1150 \mathrm{mg} / \mathrm{l}$, (b) $589 \mathrm{mg} / \mathrm{l}$, (c) $319 \mathrm{mg} / \mathrm{l}$, (d) $98 \mathrm{mg} / \mathrm{l}$, (e) $56 \mathrm{mg} / \mathrm{l}$, and (f) $15 \mathrm{mg} / \mathrm{l}$. Width and height of the image are $0.192 \mathrm{~mm}$ and $0.256 \mathrm{~mm}$, respectively.

高強度高緻密コンクリート粉末と共に水中に 2 か月保存 し，それを重量分析と顕微鏡による表面観察により岩石 試験片表面への鉱物析出を評価している。その結果，岩 石試験片表面に鉱物の析出, 重量の増加が示され, 特に 砂岩はその他の岩石に比べより多くの表面析出が示さ れている. Nakao et al.らの結果は, 本研究で得られた結 果，才なわち，カルシウムイオンを含む水中環境下にお ける試験片表面への鉱物析出が確認され，土岐花崗岩に 比べベレア砂岩がより多くの析出を確認できたことと 調和的である。

岩石表面での鉱物の析出が，濃度の高い水酸化カルシ ウム水溶液中に保存した場合に多く生じた要因として, 水中を均一かつ無秩序に安定して分散しているカルシ ウムイオンと炭酸水素イオンが反応寸る機会が増える ことが挙げられる。このことから，カルシウムイオンを
多く含む水中では岩石内のき裂が閉塞し，透水性を低下 させられる可能性があると指摘できる.

ただし，鉱物の析出による岩石の透水性の変化につい てはまだ調べることはできていない。一般に岩石の透水 係数は, 内部に存在するき裂・空陌のネットワークに影 響を受ける ${ }^{16)}$.また，透水係数の低下には，き裂・空隙 の閉塞 2),3)や開口幅の減少 17), 18)等が必要となる.ゆえに, 鉱物析出の量がこれらの現象を起こすのに十分か否か の検討および，析出をいかに促進させるかについての検 討も必要になると考えられる，例えば，より多くの二酸 化炭素を供給することにより, カルシウムイオンと二酸 化炭素の反応で生成される炭酸カルシウムの量を増大 させるようなことが必要になる可能性がある。ただし， Fig. 3 でよく示されているように, 花崗岩の個々の鉱物 粒子や粒子境界が鉱物析出により見えなくなっている 


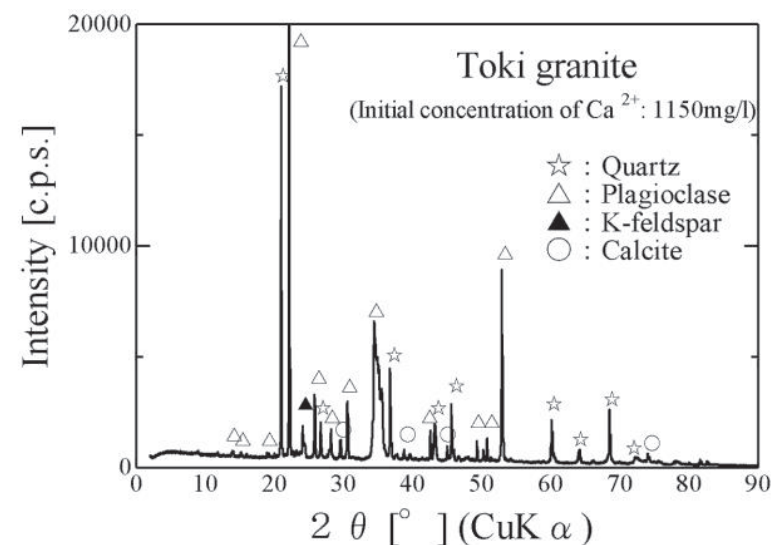

(a)

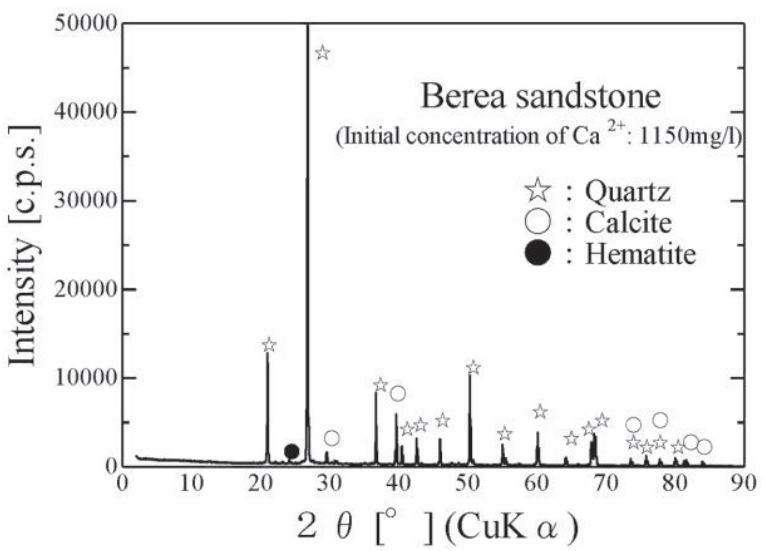

(c)

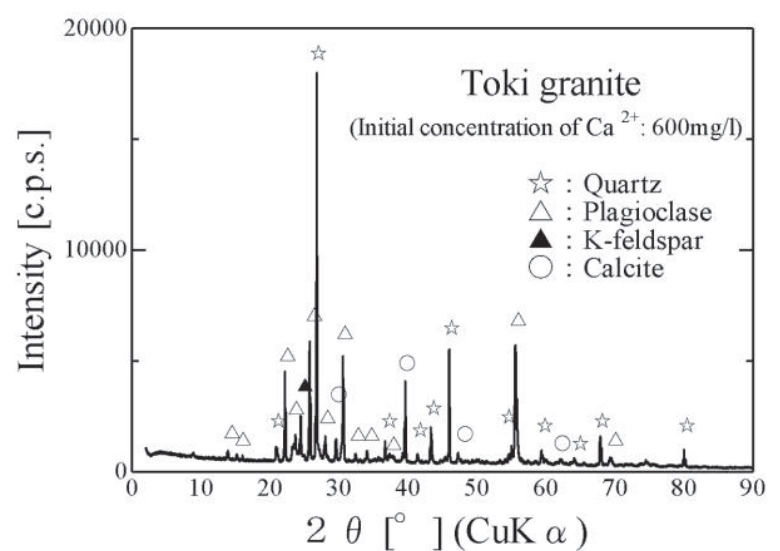

(b)

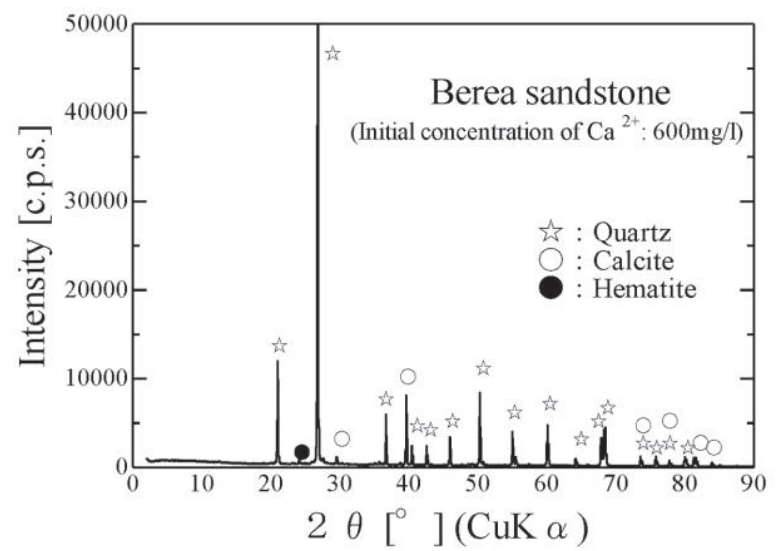

(d)

Fig. 9 Results of X-ray diffraction analysis for (a) Toki granite kept in calcium hydroxide solution with concentration of $1150 \mathrm{mg} / \mathrm{l}$, (b) Toki granite kept in calcium hydroxide solution with concentration of $600 \mathrm{mg} / \mathrm{l}$, (c) Berea sandstone kept in calcium hydroxide solution with concentration of $1150 \mathrm{mg} / \mathrm{l}$, and (d) Berea sandstone kept in calcium hydroxide solution with concentration of $600 \mathrm{mg} / \mathrm{l}$.

箇所がある。これは，粒界き裂や粒内き裂が閉塞されて いることを示唆するものである。また，Fig. 8 において よく示されているように, 砂岩の空隙構造が鉱物析出に より目立たなくなっている。これは，空隙の充填を示唆 するものといえる。これらより, 流路となりうるき裂・ 空隙のネットワークの連結性が損なわれ，岩石の透水性 が低下（または遮へい性能が向上）する可能性が指摘で きる. 自然環境下での岩石内部のき裂・空隙の閉塞は, 地質学的タイムスケールで生じるため, 工学的な応用が 難しいが，鉱物析出を利用すると，き裂や空隙の閉塞を 促進させることができ, 工学的に十分に役立てられると 考えられる. 鉱物析出の透水性への影響に関する定量評 価は本研究の目的を超えるため, 今後の研究課題とした いが，鉱物析出を岩石の透水性変化に利用寸る手法の開 発は極めて重要な課題であると指摘できる.

\section{6 結 言}

本研究では，土岐花崗岩とベレア砂岩を試料として用 い, カルシウムイオン濃度が異なる水中（水酸化カルシ ウム水溶液）に 1 ケ月保存し, 表面観察と重量測定を行 うことによって, 水中保存前後での岩石試験片表面への
鉱物析出を調査した。その結果，デジタルカメラによる 撮影では, 初期カルシウムイオン濃度が約 $600 \mathrm{mg} / 1$ を超 える環境下で保存した場合に，岩石表面での析出物が明 確に確認できた。また, 走查型電子顕微鏡で観察した結 果, 初期カルシウムイオン濃度が 100mg/1 未満の環境下 で保存した場合ではほとんど析出が生じなかったもの の，それより高い初期カルシウムイオン濃度下では，す べての試験片に鉱物の析出が確認でき, その析出量は水 中のカルシウムイオン濃度に依存することが分かった. このようなカルシウムイオン濃度が異なる条件下での 鉱物析出の程度の違いを示したことが本研究の成果で ある、また，土岐花崗岩に比べてベレア砂岩ではより多 くの鉱物析出が起こることも示された．X線回折分析を 行った結果, 析出物はカルサイトであることが確認でき た. 本研究の結果より, 鉱物の析出, 特にカルサイトの 析出による岩石内のき裂修復の可能性が示されたと考 えられる。

本研究は，「放射性廃棄物共通技術調査等事業（放射性 廃棄物重要基礎技術研究調查)」（2014～2017 年度）のサ ポートを受けて実施した。 


\section{考 文 献}

1) O. Sano, Y. Kudo and Y. Mizuta, "Experimental determination of elastic constants of Oshima granite, Barre granite, and Chelmsford granite", Journal of Geophysical Research, Vol.97, No.B3, pp.3367-3379 (1992).

2) Y. Nara, P. G. Meredith, T. Yoneda and K. Kaneko, "Influence of macro-fractures and micro-fractures on permeability and elastic wave velocities in basalt at elevated pressure", Techtonophysics, Vol.503, No.1, pp.52-59 (2011).

3) G. Wang, T.M. Mitchell, P.G. Meredith, Y. Nara and Z. Wu, "Influence of gouge thickness on permeability of macro-fractured basalt", Journal of Geophysical Research, Vol.121, pp.8472-8478 (2016).

4) M. Ishibashi, H. Yoshida, E. Sasao and T. Yugichi, "Long term behavior of hydrogeological structures associated with faulting: An example from the deep crystalline rock in the Mizunami URL, Central Japan", Engineering Geology, Vol.208, pp.114-128 (2016).

5) E.S. Sprunt and A. Nur, "Reduction of porosity by pressure solution: Experimental verification", Geology, Vol.4, pp.463-466 (1976).

6) H. Yasuhara, N. Kinoshita, H. Ohfuji, D.S. Lee, S. Nakashima and K. Kishida, "Temporal alteration of fracture permeability in granite under hydrothermal conditions and its interpretation by coupled chomo-mechanical model", Applied Geochemistry, Vol.26, pp.2074-2088 (2011).

7) D. Fukuda, Y. Nara, Y. Kobayashi, M. Maruyama, M. Koketsu, D. Hayashi, H. Ogawa and K. Kaneko, "Investigation of self-sealing in high-strength and ultra-low-permeability concrete in water using micro-focus X-ray CT", Cement and Concrete Research, Vol.42, No.11, pp.1494-1500 (2012).

8) D. Fukuda, Y. Nara, D. Hayashi, H. Ogawa and K. Kaneko, "Influence of fracture width on sealability in high-strength and ultra-low-permeability concrete in seawater", Materials, Vol.6, No.7, pp.2578-2594 (2013).

9) D. Fukuda, M. Maruyama, Y. Nara, D. Hayashi, H. Ogawa and K. Kaneko, "Observation of fracture sealing in High-strength and Ultra-low-permeability concrete by micro-focus X-ray CT and SEM/EDX”, International Journal of Fracture, Vol.188, No.2, pp.159-171 (2014).

10) Y. Nara, K. Morimoto, T. Yoneda, N. Hiroyoshi and K. Kaneko, "Effects of humidity and temperature on subcritical crack growth in sandstone", International Journal of Solids and Structures, Vol.48, No.7-8, pp.1130-1140 (2011).

11) T. Iwatsuki, R. Furue, H. Mie, S. Ioka and T. Mizuo, "Hydrochemical baseline condition of groundwater at the Mizunami Underground Research Laboratory (MIU)", Applied Geochemistry, Vol.20, pp.2283-2302 (2005).

12) M. Kato, Y. Nara, D. Fukuda, M. Kohno, T. Sato, T. Sato and M. Takahashi, "Importance of temperature control in surrounding environment during permeability test for measuring hydraulic constants of rock", Journal of the Society of Materials Science, Japan, Vol.65, No.7, pp.489-495 (2016).

13) Y. Nara, M. Kato, R. Niri, M. Kohno, T. Sato, D. Fukuda, T. Sato and M. Takahashi, "Permeability of granite including macrofracture naturally filled with fine-grained minerals", Pure and Applied Geophysics, in press (2017). doi: 10.1007/s00024-0171704-X

14) Y. Nara, R. Nakabayashi, M. Maruyama, N. Hiroyoshi, T. Yoneda and K. Kaneko, "Influences of electrolyte concentration on subcritical crack growth in sandstone in water", Engineering Geology, Vol.179, pp.41-49 (2014).

15) A. Nakao, Y. Nara, K. Kashiwaya, T. Ishida and H. Ogawa, "Observation of mineral precipitation on rock surface", Proceedings of the 8th Asian Rock Mechanics Symposium, pp.303-309 (2014).

16) Y. Gueguen and J. Dienes, "Transport properties of rocks from statistics and percolation", Mathematical Geology, Vol.21, No.1, pp.1-13 (1989).

17) P.A. Witherspoon, J.S.Y. Wang, K. Iwai, and J.E. Gale, "Validity of cubic law for fluid flow in a deformable rock failure", Water Resources Research, Vol.16, pp.1016-1024 (1980).

18) J.B. Walsh, "Effect of pore pressure and confining pressure on fracture permeability", International Journal of Rock Mechanics and Mining Sciences \& Geomechanics Abstracts, Vol.18, pp.429435 (1981). 